\title{
The diversity of traditional Malay kuih in Malaysia and its potentials
}

\author{
Mohd Yusof Bin Kamaruzaman ${ }^{1,2}$, Shahrim Ab Karim² ${ }^{*}$, Farah Adibah Binti Che Ishak ${ }^{2}$ and \\ Mohd Mursyid Bin Arshad ${ }^{3}$
}

\begin{abstract}
Malaysia is synonymously known as a multicultural country flourished with gastronomic nuances in abundance. Within the multitude of well-known savory foods available through the history of Malaysia, kuih has always bestowed a special part in the Malaysian diet. Kuih houses varying types of delicacies ranging from sweets to savory treats or snacks. As with its counterparts in the Malay cuisine, kuih has also been influenced by many historical events led by the migration of Chinese, Indians, and other explorers or visitors to Malaysia in the olden days. This casually developed the Malay kuih which now coined as the traditional Malay kuih; traditional as in the way that the classical values and authenticity were respected and established then. As time progresses and changes the lifestyle of Malays, newly innovated products are at the rise and emerged another type of kuih with somewhat similar characteristics to that of traditional Malay kuih, namely Nyonya Kuih. Nyonya kuih noted to be a reformulation of traditional Malay kuih with native Chinese expertise through some tweaks inculcating their palates and culinary library. Further along, the modernization also impacted the traditional Malay kuih in such a way that the overall representations being put at stake of unclear identity through innovations and industrializations. This paper draws out the history, authenticity, identity, and potentials of the traditional Malay kuih. Besides, this article is hoped to contribute to further refining the traditional Malay food knowledge specifically in its kuih sub-genre against the heritage-destructive modernization led by globalization.
\end{abstract}

Keywords: Traditional Malay kuih, Kuih, Traditional food, Ethnic food, Malaysia's heritage food

\section{Introduction}

Geographically, Malaysia is situated in the South-East Asia separated into two lands by the South China Sea; Peninsular Malaysia, also known as East Malaysia, and West Malaysia which is part of the Borneo Island. With its established 13 states and three federal territories, Malaysia has come a long way in creating a dynamic and colorful country as of now. It is unanimously aggregable to say that Malaysia is one of the harmonious multiracial countries. According to [1], there are three major ethnics prominently made up the 32.6 million Malaysians by 2018 namely the Bumiputeras that includes Malays at

\footnotetext{
* Correspondence: shahrim@upm.edu.my

${ }^{2}$ Department of Food Service \& Management, Faculty of Food Science \& Technology, Universiti Putra Malaysia, 43400 Serdang, Selangor Darul Ehsan, Malaysia

Full list of author information is available at the end of the article
}

$69.3 \%$, Chinese at $22.8 \%$, and Indians at $6.9 \%$. The rest of Malaysians constitute the minorities ranging in different ethnicities at 1.0\% [2]. asserted that there are actually more than 70 ethnicities in Malaysia. The diverse ethnics have longed resulted in a dynamic nuance in cultures, customs, politics, and also gastronomic outcomes. Malaysia's culinary library represents Malaysia's image including its flavor profile that is often savory, hot, and spicy [3]. Among the well known are Nasi Lemak, Rendang, Nasi Ayam, Laksa, and lots more. However, despite the common nationally claimed foods as the Malaysian flavors, individual traditional foods that explicit to each ethnicity also has their own values and uniquely different from one to another. To date, it has been reviewed and researched on the issues of traditional food as a whole but specific to a subdivision of

(c) The Author(s). 2020 Open Access This article is licensed under a Creative Commons Attribution 4.0 International License, which permits use, sharing, adaptation, distribution and reproduction in any medium or format, as long as you give appropriate credit to the original author(s) and the source, provide a link to the Creative Commons licence, and indicate if changes were made. The images or other third party material in this article are included in the article's Creative Commons licence, unless indicated otherwise in a credit line to the material. If material is not included in the article's Creative Commons licence and your intended use is not permitted by statutory regulation or exceeds the permitted use, you will need to obtain permission directly from the copyright holder. To view a copy of this licence, visit http://creativecommons.org/licenses/by/4.0/. 
these foods are on the lacking to be explored extensively, namely the traditional Malay kuih.

\section{Malay gastronomy concoction}

Being a geographically strategic country in the region of the equator, and also one of the Commonwealth countries, Malaysia certainly exudes degrees of amalgamation as historically written [4]. Factually, the state of Malacca marked the setting and time where Malaysia initially boomed with a vast array of culinary ingredients due to its trading activities with other countries and continents. As discussed by [5], this was also the point where Malays enriched their diet.

As mentioned before, the citizenship of Malaysia is predominantly Malays, but Malay ethnicity is actually residing around the globe although concentrated in the South East Asia region. Apart from Malaysia, other countries like Indonesia, Singapore, Brunei, and even southern Thailand and the Philippines are home to some Malays [4, 6]. It was written in history that Malay ethnicity itself is a mixture of several elements from Indonesia (Sumatra and Java) Thailand, Sulawesi, and Polynesia. Noting back to the introduction of this paper, the evolution of Malay cuisine itself was dynamically influenced by these ethnicities. This explains relative similarities of the Malay cuisine to certain degrees across the stated lands. Nor et al. [7] discussed that the evolution of Malay gastronomy incessantly happened in the olden days of trading where neighboring lands came in and brought the influences and in line with what is written long ago by [8] strategic geographical position of Malaysia harbored successful trading activities from around the globe. Apart from that [9-11], added that the migration of Chinese also plays a part in the creation of dynamic local cuisine.

Apart from the international influences, Malay's diet has always been associated with farming and fishing, mainly centered towards paddy fields, and vegetable and herb gardens around the house [7, 12, 13]. These include rice, coconut, pandan (screw pine leaves), ulam (native herbs and salads), poultry, fish, and spices to name a few. The spread of agricultural activities and the crops across Malaysia also partly induced by the natural resources of the land's locale. In such matters [7], contended that there are also differences of Malay foods with regard to the regional position within Malaysia. For instance, regions that technically near to the sea will have more use of seafoods in their diet as in the East-coast region that includes Kelantan and Terengganu [14]. Others would harvest "daun kayu" [14] known as the edible plants from the wild or domestically grown crops like herbs and spices and fruits. They also raise and look after livestock around the house compound and paddy cultivation where applicable. From all of the mentioned edibles [14], remarked that for ages, rural Malays acknowledged rice and fish as the main source of food.

\section{Traditional Malay kuih: an array of traditional senses}

As with other cuisine lineups, myriads of delicacies offering a range of appetizers, salads, soups, main dishes, and all the way to desserts and snacks. Within those categories, traditional Malay kuih appears to be one of the delicacies that offer versatility be fitting into an appetizer, dessert, and also as snacks [12]. Apart from nasi lemak, nasi ayam, laksa, and other popular dishes well recognized as Malaysian flavors, there are more petit treats from the traditional Malay kitchen worth further recognition in Malay cuisine, which are the kuih. The traditional Malay kuih is known as being a broad term housing various relatively small-sized delicacies ranging from scrumptious pastries or bakeries to even steamed and grilled delicacies in which each bears dynamic flavors of either sweet or savory [5]. While the term kuih itself being used loosely and due to the lack of proper documentation on such matter, the basic understanding of what traditional Malay kuih represents is still at vague. Mustafa et al. [15] even denoted traditional Malay kuih as "confectionery" which connotes a whole respect of food by itself. Besides, the word kuih itself also shares a degree of similarity to adjacent countries like Indonesia, Singapore, and Brunei, although differences in the actual meaning of kuih in stated lands would connote different types of food forms within it. Regardless, kuih is unanimously understood to be enjoyed throughout the day like snacks whenever it is available and also may occasionally be included in feasts or festivals [16].

Shamsudin et al. [17] once asserted that Malays are still consuming traditional Malay kuih as their daily diet. They also mentioned that about 70 kinds of traditional Malay kuih still popularized. These include the normally found type of kuih at street vendors that usually prepared fresh earlier the day of selling or even prepared at the stall itself. Karipap (curry puffs), apam (steamed sponge cakes), and keria (donut like kuih made from sweet potatoes and glazed in crystalized sugar) are some examples that fall into the typically found variety. These delicacies are treated as intangible heritage by the Malays and have been passed down verbally from generation to generations especially within the womenfolk [18]. Not to mention also that the habit and acceptance of new generations to consume traditional Malay kuih are inevitably have to be embedded in the family itself.

\section{Traditional ingredients}

It is suggestive that traditional Malay kuih also uses ingredients that are native to most of Malay's agricultural 
produce [9] and also what is natively grown in the wild locally [12]. While not most of the crops lend their flavors in the making of kuih, some has always been the staples across all variety of kuih namely rice from paddy cultivation, the aromatic pandan, and the famous tropical fruit, the coconuts. As with the western counterpart, ingredients of traditional Malay kuih do play their role in making the perfect traditions. The ingredients can be divided into several categories namely starches, sweeteners, liquids, lipids, and additives.

\section{Starches}

Rice is noted to be a staple food in Malaysia and specifically to the Malays. Rosniyana et al. [19] noted that rice and its products massively used in various local foods. Rice lends the starch (carbohydrate) or "body" of most kuih but not only restricted to, as glutinous rice has also contributed to some array of uses in kuih [20]. Tubers like tapioca and sweet potatoes are also called for some special recipes like bingka ubi kayu (soft tapioca slab cakes), keria, cucur badak (deep-fried savory filling sweet potato fritters), and cek mek molek (deep-fried sweet filling sweet potato fritters). Amongst all tubers, tapioca is known for the longest diet that Malay had consumed and was coined as nostalgic food by [21].

\section{Sweeteners}

Throughout history, cane sugar was undoubtedly the common sweetener used in traditional Malay kuih making. This is supported by the review made by [22] that the cane sugar industry has flourished in Malaysia by the year 1960, which driven by the British conquest of the Malaya (now Malaysia) in the midst of the year 1870. Cane sugar may be used in traditional Malay kuih making in the form of white sugar or brown sugar depending on recipes although it was not particularly specific on the coarseness grade of the grains as with western pastry and bakery production. It is worth to mention also Malays have long established and commodify a type of hardened syrup that is amorphous derived from a sugar palm tree (Arenga pinnata) called gula melaka or gula kabung. The name gula melaka is derived from the massive production of the palm sugar from Malacca state, and gula kabung is derived from the actual local name of the sugar palm tree kabung [23]. Both forms of the gula kabung and gula melaka are easily found in the local market in the form of cylindrical blocks or discs that require cook to shave them into fine crystals or chunks in accordance with specific recipes.

\section{Liquids}

Western pastries, bakeries, and desserts may always use dairy milk or cream to enhance the flavor or act as "moistener" [24] to loosen the mixture to control the texture of end products, but traditional Malay kuih uses coconut milk or coconut cream for the same reasons. Eggs (chicken or sometimes duck) also fall into the liquid category which delectably further enhances the texture of kuih especially those that resemble custard making in the makeup like seri muka (soft and chewy bed of glutinous rice with a coconut pandan custard layer) and kuih kaya gerodak (steamed flan like custard).

\section{Additives}

Additives may come as small quantity additions to the overall ingredient list that a recipe calls for. In the making of traditional Malay kuih, mostly natural flavoring, coloring, and texture enhancers were used. Pandan being the infamous ingredient in traditional Malay kuih has always been proud of its decadent aroma. Although it is understood to give lush green hue to the kuih, pandan was not used by itself for that reason. Pandan serani (Dracaena angustifolia) is said to be used for the deeper green color in kuih making. Salleh et al. [25] denoted that pandan serani has always been one of the most cultivated landscape plants in the Malays' domestic traditional landscape. Not to mention also coconut in which imparts its creamy flavor from the milk or cream and sometimes used for its flesh usually grated whether for texture enhancer in kuih lopes (steamed pate like glutinous rice cake) or as garnishing coating kuih kosui (sweet-salty wheat and tapioca flour soft cake). Figure 1 shows the use of grated coconut as garnishing to different types of traditional Malay kuih. Turmeric also sometimes used for its punchy yellow hue for savory kuih which in some kuih further flavor that particular kuih. In the same color theme, eggs also impart yellow tint to kuih on the sweeter end. These natural ingredients used as visual enhancers for the kuih to acquire varying visual attractions [26]. Besides coloring, there are other ingredients used for different purposes like rose water used for its divine aroma and limestone paste used as texturizer to enforce firmer kuih kosui and kuih lompang (little rice flour cakes with hollow center). It is also used to get red tint in cooking when used in conjunction with the presence of turmeric.

Besides the vast ingredients used, it is worth to note also that kuih spreads throughout Malaysia with differing regional preferences, for instance, the east-coasts towards the northern region of Peninsular Malaysia favors the sweeter end of kuih [5]. This region includes Kelantan, Terengganu, Kedah, and Perlis where the influence of Thailand's palates of sweet-spicy is prevalent. On the other end of the spectrum, savory kuih is widely available within the central towards the southern region of Peninsular Malaysia owing to the influences from the neighboring country, Indonesia with its salty-spicy palate. Ahmad [27] also mentioned that from her findings, east-coast kuih is leaning 


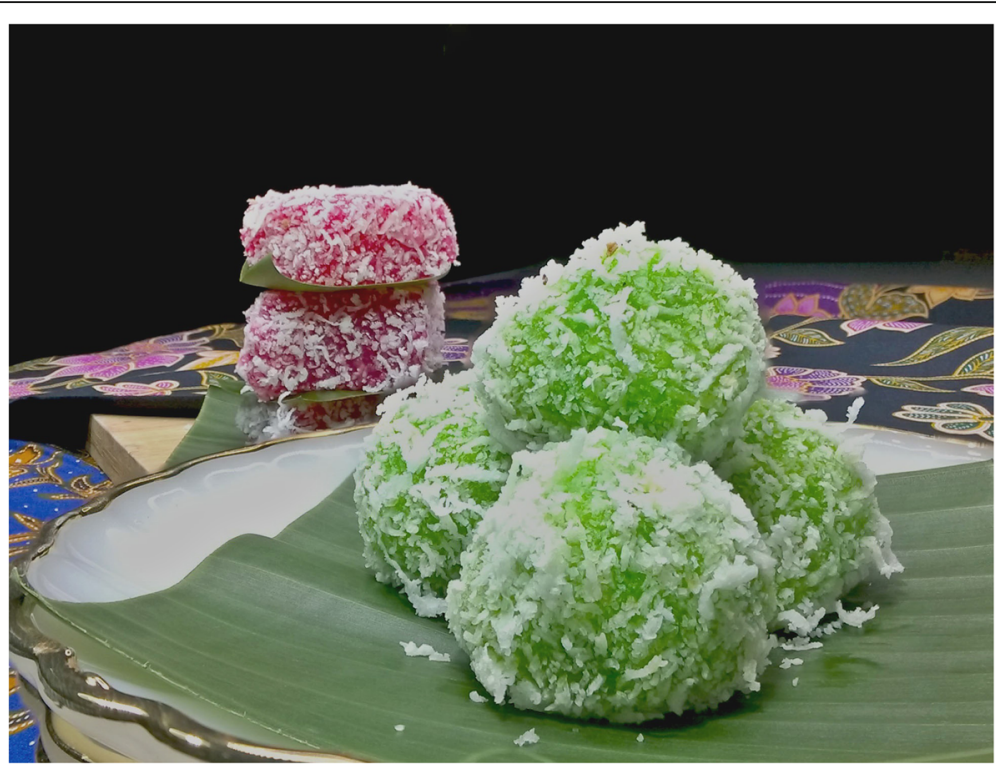

Fig. 1 Grated coconut may be used as garnishing to coat kuih buah melaka (foreground) and kuih telur katak (sticky sago) (background). Besides the aesthetical value, shredded coconut imparts interests in the texture and flavor department which makes traditional Malay kuih an all-rounded traditional delicacy. Coconut is noted to be long and widely cultivated by the Malays. Hence, it is one of the main ingredients across all traditional Malay culinary offerings. It can be used in various forms including coconut milk, coconut cream, coconut water, and also the coconut flesh itself

towards the yellow side of color and west-coast towards greener hue. She argued that the first uses more eggs into their kuih and the latter benefits more from the pandan leaves. Noting to the vast array of ingredients library, traditional Malay kuih is undoubtedly holding its identity by tying an array of delicacies with its local crops.

\section{Traditional cooking methods}

Mirroring the multitude of influences taken into the formation of traditional Malay kuih, methods of preparing the kuih are also greatly varied from baking, steaming, boiling, grilling, and more [28]. However, as Malay heritage resonates, petua (traditional tips and tricks) will come into play. Note also that the elderly as the experts of making traditional Malay kuih easily made kuih without even being too technical in terms of the measurement and advanced machines. It is once coined to be the "muscle memory" by [27] as she explained how the elderly estimate the appropriate amount of ingredients. Their expertise also covers quality checking by consistency and just the feels in their hands.

The known methods of preparing traditional Malay kuih are self-explanatory as they are remotely similar to western cooking methods in general. For example, baking is known to the world to be a dry heat cooking method that had the food put into a controlled temperature chamber and the hot air within slowly heat the pan and by adjacent heat of the pan cook the food that is in it [29]. In the making of bahulu (little individual sponge cakes), the bahulu batter will be poured into the molding cavity of a two- piece metal contraption (traditionally made of copper) that is heated with charcoal or coconut husks on the top and bottom. The adjacent heat of the metal contraption heats the batter and further cooks the bahulu. In terms of boiling and steaming, additional pandan leaves and banana leaves always called in this technique as to aromatize the kuih further like in the making of koci (mochi-like chewy black glutinous rice cake filled with sweetened grated coconut), buah melaka, lepat pisang (firm pudding-like banana cake), and others. Grilling and frying may be applied mostly to savory kuih accordingly like pulut panggang (savory filling glutinous rice grills), cucur badak, and karipap.

\section{Traditional and inspirational names}

Apart from that, the names of the kuih are also very unique to their forms and shapes [30,31]. Kuih talam, for example, used as a general term housing several kuihs that typically molded into a container normally baking tins or pans later to be cut into shapes like squares, rectangles, or traditionally diagonal cut to create diamond-shaped kuih [32,33]. Figure 2 shows the end products of various kuih talam that have been portioned into squares and diamonds. Pulut panggang derived its name from the ingredients and the method of the preparation. Pulut is glutinous rice, while panggang refers to its cooking method, grill. Figure 3 shows the visual presentation of pulut panggang. Some names of the kuih are given on the virtue of the shape the kuih is made into. Behind the delectable chewy texture and burst with 


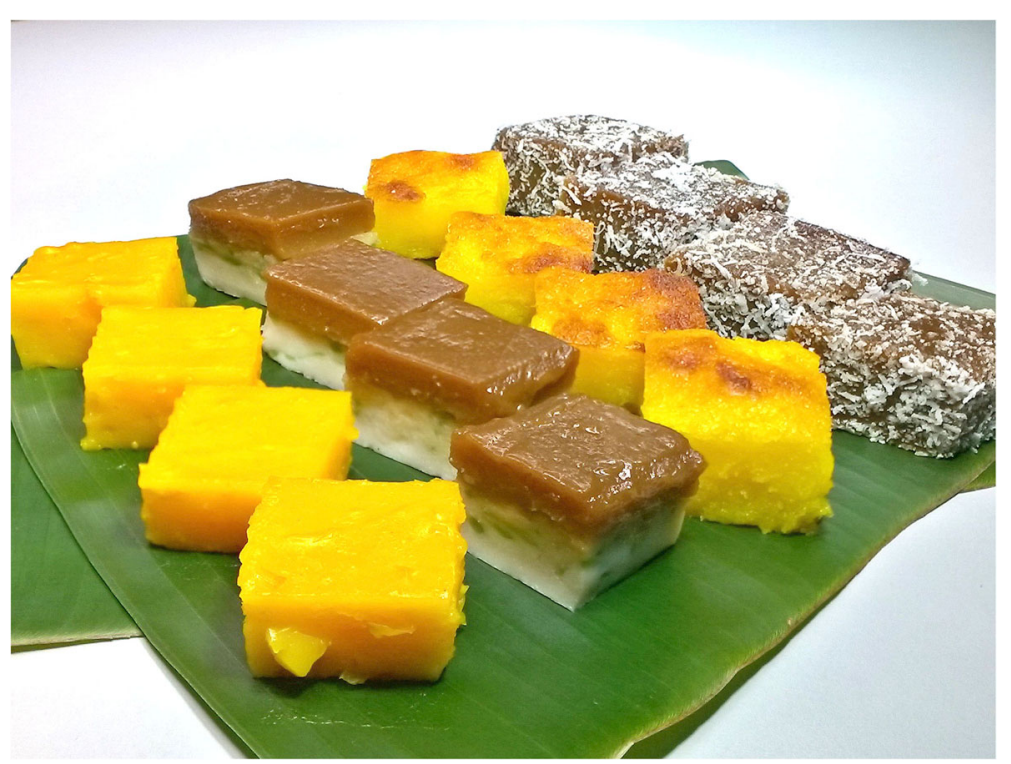

Fig. 2 An array of different kuih talam; (left to right) pudding jagung (firm corn pudding), talam cendol (green rice flour jelly with palm sugar soft cake), bingka ubi kayu, and kosui. Talam is known as a tray in English which denotes the method of making or cooking the kuih in baking tray to leave it to set before it is cut into smaller portions. This method is remotely similar to the western baking method of sheet cake like brownie, where the cakes are baked in shallow sheets only to be cut into portions prior to serving. The only difference with traditional Malay kuih is that steaming is much more practiced than baking

sweet gula kabung syrup in the middle of kuih buah melaka resides a resemblance of the small spheres of the kuih to the fruit of Malacca tree (Phyllanthus emblica), hence explained by [33] on how the kuih got its name. The Malacca tree is also notably part of important
Malaysia history where the state Malacca was given the name of [34]. Another example of kuih that named after the shape is kuih tiram. It is known to look like an oyster (tiram) shell with layers of crispy and crackling pastry when bitten. Other names can be a parable of metaphoric

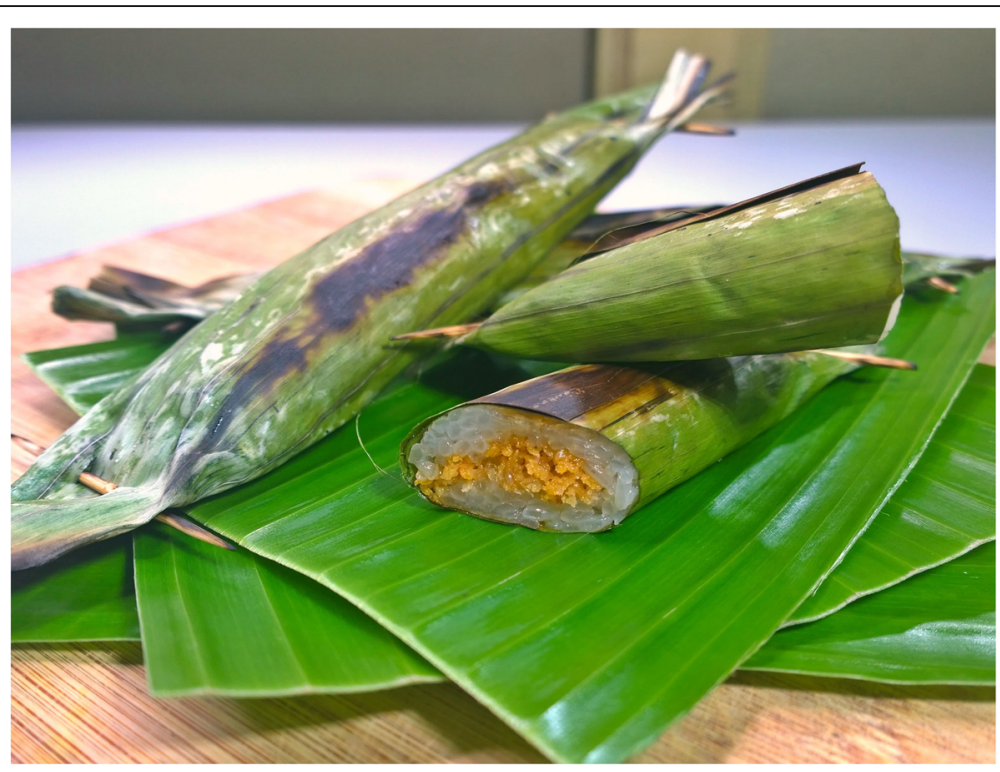

Fig. 3 A visual representation of pulut panggang. A cross-sectional view of the kuih reveals the savory filling made with grated coconut, dried shrimps, chilies, and herbs and spices that include turmeric which imparts the golden yellow hue. Banana leaf pieces are used to wrap the filled glutinous rice logs and pinned with short bamboo skewers at both ends before grilling. The aroma of banana leaf charred by the grilling heat infuses the pulut panggang giving kuih a dynamic savory flavor apart from the usual sweet kuih 
as in the case of kuih puteri dua sebilik. The literal translation reads "the two princesses of a room." While the name does not confer practical illustration [35], explained the metaphor of "two princesses" is represented by two differently colored and filled small glutinous rice balls in the kuih. These glutinous rice balls are placed together with coconut milk batter and enveloped with a piece of banana leaf that suggestively represents the "room." Figure 4 illustrates the visual appearance of the kuih puteri dua sebilik. Noting to these unique names [36], argued that historically, Malays were well versed with their literatures and poetry and thus explain the ornate metaphor of the names of certain kuih.

Having pointed out the interesting aspects of traditional Malay kuih, the extent of its product range is rather vague as no written evidence found to date. Mostly, anecdotal claims surrounding individuals and community. With all of the traditional aspects of the kuih, the lack of scholarly documentation and references of the meaning of traditional Malay kuih itself is driving these delicacies mistakenly categorized. Adding to that [37], discussed that authenticity of the kuih may be explicit to settings where it is made rather than what it is. With this, it is assured that varying versions may be presented in one type of kuih and thus lead to an unclear definition of traditional Malay kuih.

\section{Malay kuih and Nyonya kuih debacle}

In general, Baba Nyonya refers to the Malaysians that are Chinese decedents that had assimilated with the Malay cultures and customs from the olden days [38, 39]. The vast majority of this ethnic settled in Malacca, and Penang, as well as a small community in Terengganu and Kelantan [2, 10, 11]. Due to the minority, these Chinese migrants assimilate with the majority which how Malay cultures and customs affected their lifestyles. It however has not altered the religious beliefs of the Chinese from Buddhism regardless of the fluent Malay-spoken Baba Nyonyas [40].

The term Baba and Nyonya were informatively explained by [11] in his study discussing that the word "Baba" is derived from a Malay word-Bapa, that connotes a male or a father, and "Nyonya" derived from Javanese that represents the female counterpart. Additionally, the word "Peranakan" is also used to describe the Baba and Nyonya community [2, 40]. Although [10], argued that peranakan is the term used on children that born locally but from interracial wedlock between the Chinese and the local Malays. This intermingling of races urged assimilation of the Chinese to the local Malay customs and culture. The resemblance of peranakan presence and behavior to the Malay counterpart is sometimes seemed similar due to the assimilation and acculturation as discussed by [2].

As assimilation is concerned, Baba Nyonya has indefinitely acclimated to the local Malay way of life; this also includes the culinary skills [39]. This initiates the explanation of Nyonya cuisine emergence. Nyonya cuisine, in general, is a fusion concoction of the Chinese descents in Malaysia inculcating their cultural elements

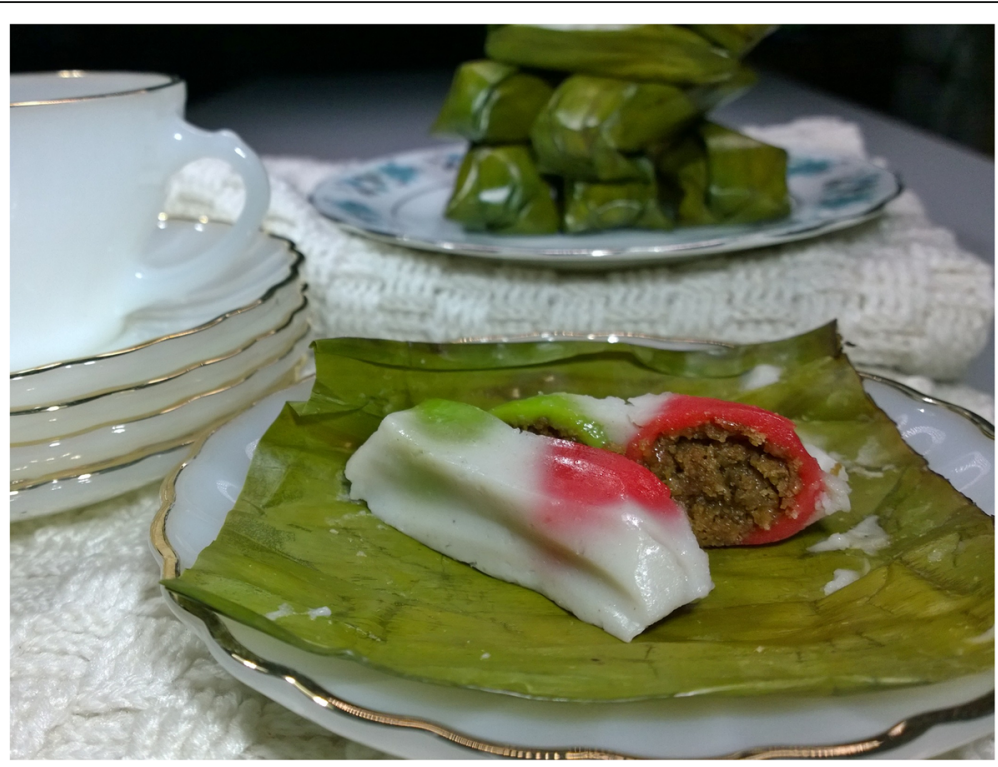

Fig. 4 Kuih puteri dua sebilik. The use of two different colored glutinous rice balls in a bed of soft coconut milk pudding. The kuih is wrapped neatly into an envelope of banana leaf. The name encapsulates the culture of Malays that are fond of poetry in their daily life. This kuih tells a story of 2 princesses that share a room together which implied by the two different colored glutinous rice balls in the kuih. The banana leaf envelope metaphorically suggests the room where the glutinous rice balls being wrapped into 
into local resources [38, 41]. The changes were not massive but rather to accommodate the peranakan's taste buds and the use of their expertise in their kitchen. These changes made upon varying traditional Malay foods and that traditional Malay kuih were also affected.

In contrast to traditional Malay kuih, Nyonya kuih sequentially flourished post-traditional Malay kuih and began to be publicly recognized since. Sua [10] noted that Nyonya kuih as essentially a modified version of traditional Malay kuih. Due to the changes made upon the traditional Malay kuih, and with the lack of documentations on the matter, some researchers have found that the confusions of traditional Malay cuisine in general are getting vaguer amongst others [42].

Nyonya kuih is now locally acknowledged to be enjoyed as snacks at any time of the day although [9] noted that Nyonya kuih usually served as light breakfast or as snacks in the afternoon. Tourism Melaka [43] on the other hand, deduced that some of the Nyonya kuih historically used as ritual offerings and also served in festive occasions like Chinese New Year. While it is overtly similar, Nyonya kuih as a brand succeeded the local market leaving traditional Malay kuih silenced. It is a shame that the original traditional Malay kuih overshadowed by its innovated counterparts. It is argued that the Nyonya kuih is produced through processes involving manual techniques to ensure quality and authenticity [43]. This is known to add up the value of the Nyonya kuih and always coined as part of advertisements.

Despite the successful story of Nyonya kuih [11], opposed that in his study, the Baba Nyonya culture was at stake of lacking its distinctions. With this, the distinct culinary features also said to face dilution through the globalization and modernization. A similar situation reported on the traditional Malay cuisine as more and more studies proven its prevalence like in the studies of $[13,18,42,44,45]$. It is however, seemingly promising for the Nyonya kuih to thrive as [11] discussed that the culture of Baba Nyonya has been entering the limelight of attention in book publications, theses, and other public awareness events. Some news also reported the value of Nyonya kuih is substantially held in the authenticity of the ingredients and methods of making which traditional and manual [43]. Even Malaysia's famous celebrity chef, Chef Wan also acknowledges the passion and manual preparation of making such delicacies as it lifts and respects the heritage and traditions [46]. It is clear that the closest representation of traditional kuih can utterly confer to quality assurance. Nyonya kuih excels in this matter undoubtedly.

\section{The states and stakes of traditional Malay kuih}

We are rained with increasing studies on heritage food as of lately. While there is a number of news on delights and concerns on the kuih in general, concentration is gravitating towards the concern of extinction on the traditional Malay kuih [15, 26, 47, 48]. And only at a lower ratio of reports on the effort on reviving the traditional Malay kuih $[49,50]$. This shows how vulnerable traditional Malay kuih status in the current scenario, leaving it on the verge of dismissal as compared to the Nyonya kuih that currently being rediscovered, rebranded, and excelled in the market. Omar and Omar [12] reported that Malay kuih sold on sides of streets offers questionable quality. These qualities being the authentic tastes, appearances, and serving style [51]. Aside from jeopardized quality, the price tag of these sellers seems to put traditional Malay kuih to just another mediocre product. Within the subject of overpricing [52], reported that the demand for quality Malay kuih is still prevalent and the willingness to pay for quality kuih is understandable. This explains that higher-priced kuih is not a reason that traditional Malay kuih left at stake, but rather the lack of quality offered.

Understanding sustainability issues, the younger generation is undoubtedly coming into mind as the next generation to inherit and reproduce traditional Malay kuih sustainably. However [18], has researched that there are prevalent challenges to sustain traditional Malay kuih in youth. This indefinitely denotes the decreasing momentum of traditional Malay kuih vitality which is feared to be extinct in the near future $[48,49]$. As the new generation moving towards digital and modernized era, redevelopments in all facets of life led by globalization and urbanization repeatedly coined to be responsible for the traditional Malay kuih decline [12, 26, 53].

Modernization is always revolving around human to uplift their lifestyle; thus, advancement in carrier proceeds traditions. No more active kitchen at home and more take-outs and eating-outs as time constraint are at excuses [54]. As traditional Malay kuih is said to be tedious and time-consuming, lesser practices performed and thus neglected for the new generation to learn which believed to be the most effective way to transmit heritage from the older generation to the new [7]. Benefitting from this matter, the business industry especially the food industry urged of doing business so intense to fulfill the gap of traditional Malay kuih demand. It is however taken for granted that attention to details of traditions in Malay kuih in general are being jeopardized [13]. As with other business intentions [51], contends that profitability is executed through the introduction of new products and also minimizing inputs in place of maximizing outputs. This lured the excessive usage of ingredients substitutions as they are relatively cost-effective and time-saving in mass production instead of the pure traditional ingredients [44]. The easily acquired and readily available modern innovated ingredients like instants and imitations reported by [13] to have altered 
the authenticity of traditional Malay cuisine and Malay kuih have no exception. Adding up to this, the technology advances from the modernization impart an inevitable degree tainting the authenticity of traditional Malay kuih. Traditional Malay kuih that was once delivered full and dynamic flavors at one bite, now tastes off from what it used to be.

Discussing within the modern era, the survival approach for new kuih entrepreneurs is not lengthy production and minimum output. Time and energy are two that are not being compromised and thus resulted them in relying on machines to accelerate the production with less consumption of energy and time $[55,56]$. This however unavoidably alters the overall quality of the kuih. Petua or known as the tips and tricks of the elderly for a perfectly made kuih is diminishing $[27,57]$ as machines are being put the trust to do the job. This decision is in line with the motto of contemporary business, where results are far admirable than processes, thus leading to deskilling, and restrict its sustainability [58]. The issue is so prevalent that Malaysia's internationally recognized chef, Chef Wan, even reported in local news to express the disappointment in professional chefs' incompetence to make traditional Malay kuih [46].

Aside from the Malay kuih supply side, a research conducted by [18] found out that the state of consumer acceptance and the overall knowledge of traditional Malay kuih among youth is at a worrying level. The extent of awareness and consumption of traditional Malay kuih affected by trends and the availability of creative modern desserts [52]. Needless to say, the overly claimed hectic work-life advancement and life in general of post globalization hinders the appreciation of the immaculate and tedious process of making traditional Malay kuih.

\section{The diversity and potentials of traditional Malay kuih}

Having discussed the traditional Malay kuih shortcomings, all is not lost as surprising demands of traditional Malay kuih prove of its market relevance locally and even those in other countries $[59,60]$. With myriads of food products available nowadays in mainstream markets, heritage food is marketed as a brand in itself that wins a niche segment of consumers who patronage its specific qualities.

Acknowledging innovation as an effort to add more values into existing products [51], Nyonya kuih proved to succeed forward as compared to its former inspiration, the traditional Malay kuih. Being treated as common food, traditional Malay kuih are easily found and might also fall into street food snacks [9]. It is, however, unfair to neglect quality factors of these heritage delicacies. Combined with the overly priced products, traditional Malay kuih is inevitably losing its pride.
In the sense of revitalization, traditional Malay kuih may need to undergo innovations as a step to levitating its pride. Having said that, the traditional quality of such heritage materials is by no chance should be disregarded [61]. A well-innovated product should hold true to its origin but better in certain ways that could enhance its value. Different aspects of innovation should be looked into like packaging or serving presentations, processing system, or even the sensitive careful selection of ingredients [62]. Kühne et al. [51] contends that there is a controversial argument on innovating traditional foods, and it is however the intention of sustaining its relevance should uphold innovation as important as to be competitive in the market among other trendy products [62]. Innovations intended include what is apparent from the consumers' view like the way that traditional Malay kuih is presented and packaging designs $[15,63]$ and also from the producers' side which can involve technological advances of machinery $[51,63]$ that is practical yet capable of producing the same traditional quality of the Malay kuih.

\section{Traditional to national: Malay kuih as Malaysian kuih}

The acknowledged heritage value of the traditional Malay kuih and other traditional food in general is at its capability of drawing warm childhood memories when the kuih consumed popularly back then [64, 65]. Given the discussed matter of the diverse versions of these kuihs throughout the vicinity of Malaysia, specific kuih and its regional authenticity can be aptly attached to varying local consumers' upbringing. These diverse potentials are sure to promise traditional Malay kuih to be marketed either into a broad or niche market segment successfully. Besides, this also helps in drawing up the colorful identity of Malays to the international level.

Speaking of identity, the differences upon flavors of each locale exude eloquent pictures of the multiracial status of Malaysia itself-a melting pot of races, cultures, and flavors [66]. Considering that the Malay kuih is widely consumed throughout the citizen, regardless of race, Malay kuih may be opted a step up for a rebrand to Malaysian kuih, making it a national food. Malay kuih has been available for a substantial timeline now and taking it up as a national food is not necessarily an exaggeration. As discussed by [67], the sharing of common food within a multiracial nation will make up as an identity determinant; thus, Malaysian kuih seemingly fit to vindicate as a brand.

With rebranding in the picture, one should be minded of the degree any changes or innovation should be introduced. Derivation of traditional may not always be appropriate for a reinvention level. As previously mentioned, the essence of heritage should not be eliminated but rather enhanced. After all, the traditional Malay kuih itself has already been concocted, consumed, and accepted for its palatability 
nationally [68]. It is, however, the concern of youth interest as the next generation to carry the heritage forward is a concern. Globalization and urbanization change the lifestyle of Malaysians tremendously, and youths are more susceptible to the trends and global standardization [18, 68]. Having said that, traditional Malay kuih also should be shed some light to be more competitive in the market and thus elevate the image into more refined and acceptable for the millennials. Nahar et al. [69] once coined that the globalization has inculcated "food neo-culturism" where youths are more accepting to what is in global trend. Keeping the product design of Malay kuih forward as Malaysian kuih, abreast with technology and consumer trends, it will surely put traditional Malay kuih to a promising market position.

\section{Conclusion}

Dynamic is another word to describe the harmonious multiracial country of Malaysia. Malaysia has proven its potentials in many ways including economics, social, and governance. Being a multiracial country, assimilations have inevitably occurred ever since historical events, and although each individual ethnicity holds dear to their beliefs and culture, Malaysians have reached a common consensus to its vast culinary library. These diverse aspects of Malaysia are making it a proud beholder of the claim of "Malaysia Truly Asia."

The common diet of Malaysians ever since the olden days always been shared across all ethnicity and traditional Malay kuih, although it connotes Malay's signature, it has always been in the diet of whole Malaysians since its existence. Every part of Malaysia's citizens had played their parts in the formation of such a group of delicacies through history, and it is only fitting for traditional Malay kuih to be rebranded into Malaysian kuih. Despite the debacle of successful marketing between traditional Malay kuih and Nyonya kuih, kuih in general is enjoyed day in and day out across all walks of life and race should not be a determinant.

Malay kuih should be celebrated as having a multitude of traditional nuances that color the Malaysian's image beautifully, and this holds great potentials in the nation's economy. With the proper adaptation of modernization and industrialization, traditional Malay kuih could be one of the thriving trades in the market, either locally or internationally. The first step should be taken in order for the next to fall into places. A precise product distinction has been established, and thus, public awareness should be campaigned. This will ensure continuity of traditional Malay kuih vitality and relevance in the market as well as the national identity. Proper planning and execution are keys to ensure the revival of traditional Malay kuih in reaching the point of heritage sustainability. The distinction and relevance of such traditional gem's existence is important for the acknowledgment and pride of generations to come.

\section{Acknowledgements \\ The authors appreciate the Universiti Putra Malaysia for the opportunity and encouragement in pursuing research on heritage and traditional food scope.}

\section{Authors' contributions}

All authors contributed to the idea and overall construction of this manuscript. The authors reviewed and approved the final manuscript.

Funding

Not applicable.

\section{Availability of data and materials}

All data and materials are used in accordance with the guideline of the Journal of Ethnic Foods as listed in the reference section. Images are personally contributed by the authors.

\section{Competing interests}

The authors declare that they have no competing interests.

\section{Author details}

${ }^{1}$ Department of Family and Consumer Science, Faculty of Technical and Vocational, Universiti Pendidikan Sultan Idris, 35900 Tanjung Malim, Perak Darul Ridzuan, Malaysia. ${ }^{2}$ Department of Food Service \& Management, Faculty of Food Science \& Technology, Universiti Putra Malaysia, 43400 Serdang, Selangor Darul Ehsan, Malaysia. ${ }^{3}$ Department of Professional Development \& Continuing Education, Universiti Putra Malaysia, 43400 Serdang, Selangor Darul Ehsan, Malaysia.

Received: 4 February 2020 Accepted: 14 May 2020

Published online: 15 June 2020

\section{References}

1. Department of Statistics Malaysia. Current population estimates, Malaysia, 2018-2019. Putrajaya: Department of Statistics Malaysia; 2019. Available from: https://www.dosm.gov.my/v1/index.php?r=column/ cthemeByCat\&cat=155\&bul_id=aWJZRKJ4UEdKcUZpT2 tVT090Snpydz09\&menu_id=LOpheU43NWJwRWVSZkIWdzQ4TIhUUT09.

2. Hun PG, Kaur C. Identiti Etnik Minoriti di Malaysia: Antara Realiti Sosial Tafsiran Autoriti dan Tafsiran Harian. Akademika. 2014 [cited 2019 Mar 28]; 84(2):57-70. Available from: http://ejournals.ukm.my/akademika/article/ viewFile/7896/3120.

3. Leong QL, Othman M, Adzahan NM, Karim MSA. A model of Malaysian food image components: towards building a sustainable tourism product. Pertanika J Soc Sci Humanit. 2012;20(2):299-315.

4. Wiryomartono B. Urbanism, place and culture in the Malay world: the politics of domain from pre-colonial to post colonial era. City, Cult Soc. 2013;4(4):217-27. Available from: https://doi.org/10.1016/j.ccs.2013.05.004.

5. Raji MNA, Karim SA, Ishak FAC, Arshad MM. Past and present practices of the Malay food heritage and culture in Malaysia. J Ethn Foods. 2017:4(4): 221-31 Available from: http://linkinghub.elsevier.com/retrieve/pii/\$235261 8117301737.

6. Wallace AR. The Malay archipelago. Revised ed. Boston: Periplus Editions; 2008. p. 512.

7. Nor NM, Sharif MSM, Zahari MSM, Salleh HM, Isha N, Muhammad R. The transmission modes of Malay traditional food knowledge within generations. Procedia Soc Behav Sci. 2012;50(November 2014):79-88 Available from: http://linkinghub.elsevier.com/retrieve/pii/S1877042812031552.

8. Braddell R. An introduction to the study of ancient times in the Malay Peninsula and the Straits of Malacca. J Malayan Branch R Asiat Soc. 1935; 15(3):64-126.

9. Karim MSA, Halim NA. Street food: culture, economy, health and governance. In: de Cardoso R, CV, Companion M, Marras SR, editors. . 1st ed. New York: Routledge; 2014. p. 1-301.

10. Sua T. Akulturasi Peranakan Cina di Tirok, Terengganu. J Terjem Alam Tamadun Melayu [Internet]. 2011 [cited 2019 Mar 28];2:2(2):151-62. Available from: http://www.ukm.my/terjemah/images/terjemah/makalah/J. Terjemahan_22Jun201109new.pdf. 
11. Kim LS. The Peranakan Baba Nyonya culture: resurgence or disappearance ? Sari. 2008;26(2008):161-70.

12. Omar SR, Omar SN. Malaysian heritage food (MHF): a review on its unique food culture, tradition and present lifestyle. Int J Heritage, Art Multimed. 2018;1(3):1-15.

13. Ismail NA, Karim MSA, Othman M, Halim NA. The values of the traditional culinary practices towards the modernization as perceived by the Malay Chef in Klang Valley. Mediterr J Soc Sci. 2013;20(5):2857-64.

14. Laderman C. Food ideology and eating behavior: contributions from malay studies. Soc Sci Med. 1984;19(5):547-59 Available from: https://linkinghub. elsevier.com/retrieve/pii/0277953684900509.

15. Mustafa M, Nagalingam S, Tye J, Shafii ASH, Dolah J. Looking back to the past: revival of traditional food packaging. In: 2nd Regional Conference on Local Knowledge (KEARIFAN TEMPATAN). Jerejak Island. 2012:1-17.

16. Kamaludin H. 10 Kuih Tradisional Melayu: Mana Satu Anda Suka? Sinar Online. Feb. 2017:9:1-8.

17. Shamsudin S, Dardak RA, Ahmad SA. Potensi Pasaran Kuih-Muih Tradisional Sejuk Beku Di Selangor. Econ Technol Manag Rev. 2014;9b(2014):163-70.

18. Hamzah H, Karim MSA, Othman M, Hamzah A, Muhammad NH. Challenges in sustaining the malay traditional kuih among youth. Int J Soc Sci Humanit. 2015;5(5):472-8 Available from: http://www.ijssh.org/index.php?m= content\&c=index\&a=show\&catid $=55 \&$ id $=825$.

19. Rosniyana A, Hazila KK, Hashifah MA, Norin SAS. Nutritional composition and sensory properties of kuih Baulu incorporated stabilised rice bran. J Trop Agric Food Sci. 2011;39(1):1-9.

20. Muhammad R, MSM Z, ASM R, Ahmad R. The roles and symbolism of foods in Malay wedding ceremony. Procedia Soc Behav Sci. 2013;101:268-76 Available from: http://linkinghub.elsevier.com/retrieve/pii/S1877042813020958.

21. Nur. Koleksi Resipi Masakan Guna Ubi Kayu. Makanan Popular Nostalgia Zaman Jepun. Rasa. 2018 [cited 2019 Sep 26]. p. 1-33. Available from: https://www.rasa.my/koleksi-resipi-masakan-guna-ubi-kayu-makananpopular-nostalgia-zaman-jepun/.

22. Danu N. Industri Gula Dan Implikasi Sosial Dan Ekonomi Masyarakat Perlis, Satu Tinjauan Sejarah, 1970-1990. In: Prosiding Seminar Institusi Raja. 2014 p. 1-14. Available from: http://dspace.unimap.edu.my:80/dspace/ handle/123456789/35709.

23. Ishak MR, Sapuan SM, Leman Z, Rahman MZA, Anwar UMK, Siregar JP. Sugar palm (Arenga pinnata): Its fibres, polymers and composites. Carbohydr Polym. 2013;91(2):699-710 Available from: https://doi.org/10.1016/j.carbpol. 2012.07.073.

24. Paula F. How Baking Works. 3rd ed. Hoboken: Wiley; 2011. p. 1-531.

25. Salleh $I H$, Rashid MSA, Sakip SRM. Malay garden concept from the traditional Malay landscape design. Procedia Soc Behav Sci. 2016;222(2016): 548-56 Available from: https://linkinghub.elsevier.com/retrieve/pii/S1877042 816302907.

26. Dolhamid NF. Lestarikan Sajian Melayu Agar Tak Luput Dek Zaman. Berita MediaCorp. 2015 [cited 2018 Feb 22];2-4. Available from: https://berita. mediacorp.sg/mobilem/lifestyle/lestarikan-sajian-melayu/1779836.html.

27. Ahmad H. Projek KWIH: Kuih Warisan Ihsan Haridepan. UiTM Puncak Alam; 2019 p. 1-61.

28. Mok O. Malaysian kuih: a marriage of flavours and cultures. Malaymailonline. 2016 Mar;1-14. Available from: http://www.themalaymailonline.com/eatdrink/article/malaysian-kuih-a-marriage-of-flavours-and-cultures\#bgQfTOr6 F35ozpbH.97.

29. Gisslen W. Professional Baking. 6th ed. Hoboken: Wiley; 2013. p. 1-812.

30. Koh J. Ultimate guide to Malaysian kuih: how well do you know your kuih? Timeout.com. 2016 [cited 2019 Apr 11]. Available from: https://www. timeout.com/kuala-lumpur/restaurants/ultimate-guide-to-malaysian-kuih.

31. Radzi SBM. Pembuatan Dan Penamaan Kuih-Muih Tradisional Melayu: Universiti Teknologi MARA; 2016.

32. Penseladmin. Jom Tengok Cara Nak Buat - 10 Resepi Kuih Talam Pelbagai Jenis Yang Menjadi 'Favourite' Anda. Pensel Pen. 2018. p. 1-27. Available from: penselpen.com/2018/06/13/jom-tengok-cara-nak-buat-10-resepi-kuihtalam-favourite-anda/.

33. Aleiya N. Kuih Tradisional. Blog. [cited 2019 May 20]. p. 1-6. Available from: https://aleiya98.weebly.com/pengenalan-mengenai-kuih-muih.html.

34. Forest Research Institute Malaysia. The Legendary Melaka Tree. Ministry of Water, land and natural Resources. 2014 [cited 2019 Sep 30]. p. 1-2. Available from: https://www.frim.gov.my/colour-of-frim/the-legendarymelaka-tree/.
35. Fatimah. Puteri Dua Sebilik. Patyskitchen. 2015 [cited 2019 Sep 30]. p. 1-15. Available from: patyskitchen.blogspot.com/2015/07/iftat-treat-puteri-duasebilik.html.

36. Kosasih HE. Nilai-nilai Moral Dalam Karya Sastra Melayu Klasik Islam: Kajian Terhadap Hikayat Raja Khaibar, Hikayat Saif Zulyazan, serta Hikayat Mariam Zanariah dan Nurdin masri. SUSURGALUR J Kaji Sej Pendidik Sej. 2013;1(1):11-26.

37. Muhammad R, Zahari MSM, Shariff MSM, Abdullah KM. Malaysian foodways: acculturation/assimilation towards authenticity sustainability among diasporic community. Procedia Soc Behav Sci. 2016;222(2016):367-73 Available from: http://linkinghub.elsevier.com/retrieve/pii/S1877042816302592.

38. Penang Global Tourism. Penang: Babab Nyonya Heritage. Penang: Penang Global Tourism; 2017. p. V02Mar17.

39. Chee-Beng T. Chinese identities in Malaysia. Asian J Soc Sci. 2008;25(2):103-16.

40. Ng CY, Karim AS. Historical and contemporary perspectives of the nyonya food culture in Malaysia. J Ethn Foods. 2016;3(2):93-106 Available from: https://doi.org/10.1016/j.jef.2016.05.004.

41. Bowen RL, Devine CM. "Watching a person who knows how to cook, you'll learn a lot" Linked lives, cultural transmission, and the food choices of Puerto Rican girls. Appetite. 201 1;56(2):290-8 Available from: https://doi.org/ 10.1016/j.appet.2010.12.015.

42. Aziz AR, Pawi AAA. Redefining Malay food in the post Malaysia's new economic policy (NEP). J Tour Hosp Culin Arts. 2016;8(2):1-9.

43. Tourism Melaka. Kehalusan Pembuatan Kuih Nyonya Lebih Dari Tradisi Semata-mata. Destinationmelaka.my. 2016 [cited 2019 Apr 11]. Available from: http://www.destinationmelaka.my/article/kehalusan-pembuatan-kuihnyonya-lebih-daripada-tradisi-semata-mata.html.

44. Sharif MSM, Nor NM, Rahman AEA, Abdullah KM. The modernization of Malay food ingredients: a qualitative investigation. Environ Proc J. 2016;1 (3): 227 Available from: http://ebpj.e-iph.co.uk/index.php/EBProceedings/article/ view/367.

45. Zahari MSM, Salleh HM, Sharif MSM, Noor NM, Ishak N. Malay traditional food knowledge and young generation practices. Sci Ser Data Rep. 2013; 5(4):14-24.

46. Chu MM. Chef Wan : Home cooks good at dishing out region 's delicacies: The Star Online; 2018. p. 1-3.

47. Utusan Online. Pelihara Resipi Kuih Tradisional. Utusan Online. 2017;1-8. Available from: http://www.utusan.com.my/berita/nasional/pelihara-resipikuih-tradisional-1.573803.

48. Halwa maskat semakin dilupakan. Sinar Harian. 2015 [cited 2018 Feb 22];25. Available from: http://www.sinarharian.com.my/edisi/utara/halwa-maskatsemakin-dilupakan-1.420682.

49. Arsad MM. Pertahan Kuih Tradisional. Utusan Malaysia. 2018;22. Available from: http://www.utusan.com.my/berita/wilayah/johor/pertahan-kuihtradisional-1.584148.

50. Karim LAA. Usaha Pulihara Kuih Warisan Tradisional, Elak Pupus. Berita Harian. 2018 [cited 2018 Feb 22];1-14. Available from: https:/www.bharian. com.my/bisnes/lain-lain/2018/01/373817/usaha-pulihara-kuih-warisantradisional-elak-pupus.

51. Kühne B, Vanhonacker F, Gellynck X, Verbeke W. Innovation in traditional food products in Europe: do sector innovation activities match consumers' acceptance? Food Qual Prefer. 2010;21(6):629-38.

52. Saidi N. Kuih Melayu Semakin Pupus. Utusan Online. 2018;1-5. Available from: https://www.utusan.com.my/mega/kuih-melayu-semakin-pupus-1.752093.

53. Zakariya K, Kamarudin Z, Harun NZ. Sustaining the cultural vitality of urban public markets: a case study of Pasar Payang. Malaysia. 2016;10(1):228-39.

54. Ali N, Abdullah MA. The food consumption and eating behaviour of Malaysian urbanites: issues and concerns. Malaysia J Soc Sp. 2012;8(6):157-65.

55. Hassan S, Hehsan H, Khairu K, Faizal E, Sardan AS, Salim NA, et al. Development of automated control system for kuih Penderam stamping machine. Appl Mech Mater. 2015;773-774(2015):888-92 Available from: https://www.scientific.net/AMM.773-774.888.

56. Kob CGC, Mydin HMM. Bin. The development of topping cake machine. J Machanical Manuf. 2014;1(2014):88-92.

57. MSM S, MSM Z, Nor NM, Muhammad R. Factors that restrict young generation to practice Malay traditional festive foods. Procedia Soc Behav Sci. 2013;101:239-47 Available from: http://inkinghub.elsevier.com/retrieve/ pii/S1877042813020922.

58. MSM S, MSM Z, Nor NM, Muhammad R. The importance of knowledge transmission and its relation towards the Malay traditional food practice continuity. Procedia Soc Behav Sci. 2016;222:567-77 Available from: http:// linkinghub.elsevier.com/retrieve/pii/S1877042816302920. 
59. Haimid MT, Wahab MAMA, Dardak RA, Rahim H, Shamsudin S, Nizat MNM Consumer afinity for frozen traditional cakes in Selangor. Econ Technol Manag Rev. 2014;9(a)(2014):81-9.

60. Vanhonacker F, Lengard V, Hersleth M, Verbeke W. Profiling European traditional food consumers. Br Food J. 2010;112(8):871-86 Available from: http://www.emeraldinsight.com/doi/10.1108/00070701011067479.

61. Abdul AR. Heritage conservation: authenticity and vulnerability of living heritage sites in Melaka state. Kaji Malaysia. 2017;35(Supp.1):39-58 Available from: http://web.usm.my/km/35(Supp.1)2017/km35s12017_3.pdf.

62. Guerrero L, Guàrdia MD, Xicola J, Verbeke W, Vanhonacker F, ZakowskaBiemans $\mathrm{S}$, et al. Consumer-driven definition of traditional food products and innovation in traditional foods. A Qualitative Cross-cultural Study. Appetite. 2009;52(2):345-54.

63. Rahman HA. Makanan Tradisional Masyarakat Malaysia. 1st ed. Johor Bahru: Percetakan Bumi Restu Sdn. Bhd; 2016. p. 1-129.

64. Gellynck X, Banterle A, Kühne B, Carraresi L, Stranieri S. Market orientation and marketing management of traditional food producers in the $\mathrm{EU} . \mathrm{Br}$ Food J. 2012;114(4):481-99.

65. Edson G. Heritage: pride or passion, product or service? Int J Herit Stud. 2004;10(4):333-48

66. Omar M, Adzahan NM, Ghazali HM, Karim R, Halim NMA, Karim SA. Sustaining traditional food: consumers' perceptions on physical characteristics of Keropok Lekor or fish snack. Int Food Res J. 2011;18(1):117-24.

67. Zahari MSM, Tumin A, Hanafiah MH, HNA M. How the acculturation of Baba Nyonya community affects Malacca food identity? Asian Ethn. 2019;20(4): 486-502 Available from: https://doi.org/10.1080/14631369.2019.1605825.

68. Muhammad NH, Othman M, Ghazali H, Karim MSA. Investigating traditional food eating habits among urban and rural youths in Selangor, Malaysia. Int J Soc Policy Soc. 2013;10(2013):28-44.

69. Nahar N, Karim MSA, Karim R, Ghazali H, Krauss SE. The globalization of Malaysia National Cuisine: a concept of "gastrodiplomacy.". J Tour Hosp Culin Arts. 2018;10(1):42-58.

\section{Publisher's Note}

Springer Nature remains neutral with regard to jurisdictional claims in published maps and institutional affiliations.

Ready to submit your research? Choose BMC and benefit from:

- fast, convenient online submission

- thorough peer review by experienced researchers in your field

- rapid publication on acceptance

- support for research data, including large and complex data types

- gold Open Access which fosters wider collaboration and increased citations

- maximum visibility for your research: over $100 \mathrm{M}$ website views per year

At $\mathrm{BMC}$, research is always in progress.

Learn more biomedcentral.com/submissions 